\title{
МЕТАФТОНІМІЯ \\ ЯК ОСНОВА ЕВФЕМІЗМІВ ТІНЬОВОЇ ЕКОНОМІКИ В АМЕРИКАНСЬКОМУ ПОЛІТИЧНОМУ ДИСКУРСІ
}

\author{
Леся Небелюк \\ Прикарпатський національний університет імені Василя Стефаника, \\ вул. Шевченка, 57, м. Івано-Франківськ, Украӥна, 76018 \\ lesia.nebeliuk@gmail.com
}

\begin{abstract}
Анотація. У статті проаналізовано евфемізми на позначення тіньової економіки в американському англомовному політичному дискурсі, які утворені на основі метафтонімії. Показано лексикосемантичні зв'язки зі сфер знань реципіснта, що сприяють позитивному сприйняттю евфемізмів через метонімічне розширення концептуальної метафори. Для аналізу концептуальних метафор із метонімічним розширенням, які лежать в основі евфемістичних одиниць, застосовано теорію концептуальної інтеграції. Виявлено тенденцію конфлікту протилежних смислів в евфемізації американського політичного дискурсу. Описано особливості асоціативного сприйняття досліджуваних евфемізмів у мовленні та їхній вплив на когніцію реципієнтів.

Ключові слова: евфемізм, концептуальна метафора, метонімія, метафтонімія, концептуальна інтеграція, політичний дискурс.
\end{abstract}

Вступ. Тіньова економіка як діяльність, що приносить нелегальний дохід, $\epsilon$ негативним явищем у будь-якій країні. Навіть у таких розвинених країнах як США, теж $є$ місце цьому явищу і воно потребує евфемізації для зменшення негативної реакції реципієнтів на нього.

На сучасному етапі феномен евфемізму все більше абстрагується від поняття стилістичного засобу і переходить у політичну та соціальну сфери життя, набуваючи маніпулятивного характеру. Евфемізм також стає все непомітніше "прихованішим" у політичному дискурсі: реципієнти часто не виокремлюють його як такий, але маніпулятивний ефект при цьому не зменшується. Такий вплив і потенціал евфемізмів $\epsilon$ результатом дії метафтонімії у їхній основі. Отже, метою статті $є$ аналіз евфемізмів тіньової економіки, утворених на основі метафтонімії, в американському англомовному політичному дискурсі.

Аналіз останніх досліджень і публікацій. Дослідження евфемізмів до сьогодні здебільшого проводили в рамках стилістичних, лексико-семантичних чи функціонального-прагматичних розвідок [2; 13]. В. Великорода стверджує, що наукові праці та монографії (А. Кацев, Н. Босчаєва, К. Хем, Дж. Лоуресн, В. Ноубл, К. Аллан, К. Баррідж, І. Алєксєєв, С. Відлак, В. Кравченко, Б. Ларін), засвідчують виникнення різних підходів до трактування явища евфемізації в англійській мові. Розбіжності торкаються способів творення евфемізмів, визначення мотивів їх вживання мовцями,

(С) Небелюк Л., 2019 
класифікації евфемічної лексеми, сфер дистрибуції евфемізмів, їх прагматичних особливостей функціонування та стильової належності $[2$, с. 1]. Сама ж науковець у своїй праці досліджувала способи та засоби творення евфемізмів, динаміку функціонування евфемічного словника, особливості взаємодії евфемічної лексеми 3 табу, арго та “політичною коректністю” та функціонально-прагматичний поділ евфемічних субститутів [2, с. 1]. Проте лінгвокогнітивні характеристики евфемізмів і когнітивні процеси евфемізації небажаних аспектів реальності в політичному дискурсі залишаються поза увагою лінгвістів, що й спонукало автора презентованого дослідження до написання цієї статті.

У попередніх працях [4; 5] ми виокремлювали лінгвокогнітивні характеристики евфемізмів американського політичного дискурсу англійської мови, які мали в основі концептуальні метафори, але для розуміння їхніх понятійних сфер (сфер-джерел) не застосовувалось метонімічне розширення, оскільки джерело метафори було зрозумілим i, відповідно, метафоричний сценарій легко відтворювався [7, с. 196]. До нашої вибірки ввійшли евфемізми на позначення тіньової економіки американського політичного дискурсу, когнітивні механізми творення яких не є чіткими, а джерело метафори не завжди легко досяжним. Усе ж можна простежити певний метонімічний зв'язок між евфемізмом та явищем, яке він позначає. Таким чином, ми розглядатимемо ці евфемізми як такі, що утворені на основі метафтонімії (інтеграція метафори та метонімії), оскільки такий спосіб дає можливість дослідити лінгвокогнітивні характеристики таких евфемізмів [6]. Маніпулятивний ефект може здійснюватись і завдяки одній із основних функцій метонімії, яка є складовою метафтонімії: висування вперед певного потрібного аспекту і відхилення інших, не таких бажаних аспектів, на задній план [7, c. 199].

Методологія дослідження. Поняття евфемізму ми трактуємо за визначенням В. Б. Великороди: "Евфемізми - одиниці вторинної номінації з відносно позитивною конотацією, що використовують для заміни прямих найменувань, уживання яких iз соціально чи психологічно зумовлених причин вважається небажаним" [2, с. 5]. Матеріалом дослідження стали політичні евфемізми, виявлені у періодичних англомовних виданнях засобів масової інформації “The New York Times” та "The Washington Post", опублікованих у 2003-2019 pp.

Звернення до когнітивних основ явища евфемії дає змогу розглядати евфемізацію як механізм формування нового сенсу (поняття), в основі якого лежать певні схеми і моделі вторинної інтерпретації знань. 3 цього погляду евфемізація представляє собою окремий випадок концептуальної деривації - модель зміни певного концептуального змісту 3 метою формування нового [1, с. 5-6]. Це стає можливим в результаті дії механізмів генералізації, депрофілювання, аконкретизації, концептуальної метафори, метонімії [1, с. 7]. Тобто евфемізм утворюється на основі певного концепту, який може виражатися концептуальною метафорою, а в результаті утворюється новий, покращений зміст цього концепту.

Евфемізація, хоч і полягає у відході від прямої номінації, не передбачає повну нейтралізацію змістовних характеристик вихідного концепту [1, с 6]: потрібно, щоб реципіснт все ж таки розумів, про що йде мова. 
Для аналізу та виокремлення лінгвокогнітивних характеристик евфемізмів ми застосовуємо теорію концептуальної інтеграції Г. Фоконьє та М. Тернера. Згідно з цією теорією, виділяють чотири основні ментальні простори: два вхідні простори (Input Space 1, Input Space 2), до яких входять так звані сценарії; родовий простір (Generic Space), що представляє концептуальну структуру, яка властива двом вхідним просторам, та вихідний простір (Blended Space), де матеріали з двох вхідних просторів поєднуються, взаємодіють та утворюють новий смисл, який несе в собі евфемізм [12, с. 101]. Теорії концептуальної інтеграції також властива проекція метонімічного розчеплення (зв'язку), коли елемент проектується з вхідного простору до вихідного простору, а другий елемент з того ж самого простору проектується до вихідного простору через свій метонімічний зв'язок з першим та скорочує метонімічну відстань між ними у вихідному просторі $[10$, с. 46]. Таким чином, при проекції з однієї концептуальної сфери в іншу можлива активація одного з елементів сфери і його переосмислення як суміжного, або суміжна проекція елементу однієї сфери потребує концептуального розширення за схожістю [7, с. 195].

Л. Гуссенс детальніше дослідив це явище метонімічного розчеплення у процесі концептуальної інтеграції і запровадив термін "метафтонімія" - концептуальна взаємодія між метафорою та метонімією [11]. Він був першим, хто заговорив про власне взаємодію метафори та метонімії $[14$, с. 8$]$. Ми погоджуємося із думкою О. С. Шарманової, яка стверджує, що метафтонімія є видом взаємодії, в якому метафоричне джерело потребує метонімічного розширення, або має в своїй основі метонімічні корені. В основі метафтонімії лежить метафоричне проектування елементів сфери-джерела на елементи сфери-цілі. При цьому елементи однієї із сфер мають метонімічне розширення, тобто потребують метонімічного розвитку поняття, або мають метонімічну основу [7, с. 197].

В межах теорії концептуальної інтеграції можливість поєднання елементів на основі метонімічних зв'язків дає вихідному простору великий потенціал: вихідний простір може поєднати елементи, які підсилюють бажаний ефект навіть якщо ці елементи не є відповідниками. Отже, метафтонімія може слугувати когнітивною основою евфемізмів для створення імпліцитного впливу на реципієнтів, викривлюючи сприйняття реальності через поєднання непоєднуваних понять, тобто “маскуючи" негативні явища під позитивні.

Метонімія слугує засобом для повного осягнення смислів, які можливо вивести 3 метафори [14, с. 11]. Підсилення метонімій через проекцію до вихідного простору із вхідного простору може допомогти оптимізувати інтеграцію у вихідному просторі, створюючи компактнішу і легшу одиницю маніпуляції.

Оскільки меліоративний ефект висловлення досягається внаслідок дії когнітивних механізмів [1, с. 11], ми вважаємо доречним розглядати евфемізми тіньової економіки американського політичного дискурсу як такі, що утворилися на основі дії концептуальних метафор, в яких простежується метонімічне розширення, тобто розглядатимемо їх як утворених на основі метафтонімії. Застосування теорії концептуальної інтеграції для виокремлення лінгвокогнітивних характеристик досліджуваних евфемізмів, утворених на основі метафтонімії, надає можливість проаналізувати процес переконцептуалізації, виділити нові, короткочасні концептуалізації, які є результатом інтеграції, що може 
призвести до зміни погляду (думки) реципієнта та реакції на явища тіньової економіки в американському політичному дискурсі. Оскільки у вихідному просторі можуть відображатися приховані авторські смисли [3, с. 10], то аргументи та ідеї, розвинуті у вихідному просторі, можуть мати вплив на мислення, викликаючи у реципієнтів змінене сприйняття початкових вхідних просторів та зміну думки щодо відповідної ситуації [10, с. 138].

Результати дослідження та їхнс обгрунтування. У своїй передмові до словника евфемізмів Р. Голдер пише: “Іноді доводилося пояснювати один евфемізм за допомогою іншого. 3 деякими словами це неминуче, тому що немає синонімів до деяких слів, які б не були евфемізмами. < .. > Через те, що багато евфемізмів стали частиною стандартної англійської мови і ми думаємо тільки про поточне вживання, мені іноді доводиться нагадувати читачу про пряме значення певних слів". [13, с. 7-8]. Таким чином, евфемізм стає механізмом творення нових смислів.

У метафорах, що увійшли до когнітивних основ евфемізмів тіньової економіки, ми використовуємо для аналізу власне евфемізм black economy, що в словнику евфемізмів трактується як сума товарів і наданих послуг без офіційної реєстрації або без оподаткування [13, с. 98]. Цей евфемізм настільки вкорінився в мову, що сприймається як термін економіки, адже саме як такий він подається у словнику [8]. У цій статті ми не досліджуємо лінгвокогнітивні характеристики евфемізму black economy, а тільки використовуємо його у побудові концептуальних метафор для зручності та компактності при позначенні такого явища, як тіньова економіка.

До нашої вибірки увійшли такі евфемізми як merger accounting (the false statement of subsequent profitability), parallel importer (smuggles commodities), informal market (a gathering functioning in a street without an official license), expenses (an additional taxfree emolument). Нижче наведемо кілька цитат для ілюстрації та проаналізуємо деякі $з$ вищевказаних евфемізмів детальніше у контексті. Перший приклад: The Environmental Protection Agency should consider recovering nearly \$124,000 in improper travel expenses by former EPA chief Scott Pruitt... The findings, issued nearly a year after Pruitt resigned amid controversy over his spending, travel and ties to lobbyists and outside groups, highlight the fiscal impact of his penchant for high-end travel and accommodations (The Washingtom Post, 16/05/2019).

У наведеній цитаті автор, хоч і вказує на те, що подорожі посадовця коштували надто дорого, та все ж не говорить прямо про привласнення державних коштів, подаючи це як неправильні витрати. Це не викликає у реципієнтів різко негативних асоціацій, адже самі по собі витрати навіть, якщо вони і нераціональні, не є обов'язково злочином. Нераціональні витрати скоріше асоціюються з помилкою, недостатньою інформацією тощо, тобто евфемізм expenses сприймається як звичайне економічне явище.

Другий приклад: Regulators May Be Clamping Down on Merger Accounting. Two years ago, corporate America breathed a sigh of relief as a new merger accounting rule took effect. No longer would "good will" amortization lower corporate profits (The New York Times, 04/07/2003).

Дослівно термін merger accounting означає процес підготування фінансової документації згідно з стандартом фінансової звітності у процедурах придбання та 
злиття [9]. Проте цей термін набув евфемічного значення (став одиницею вторинної номінації) і означає неправдиву звітність щодо прибутковості.

Можна простежити метонімічний зв'язок поданих вище евфемізмів із явищами, які вони позначають. Оскільки економічна діяльність охоплює і такі негативні явища, як неправдиві звіти, занижування цін, приховування прибутків та ін., стає помітною метонімічна модель ЦІЛЕ замість ЧАСТИНИ (де цілим є економічна діяльність, а засоби тіньової економіки становлять їі частини). Таким чином, не наголошується факт порушення: йдеться про такі види економічної діяльності, як процес звітності, витрати, ринок, імпорт, причому ухиляння від податків та подання неправдивих даних при цих процесах відходять на задній план і залишається поза увагою реципієнтів.

Отже, вищенаведені евфемізми зводимо до спільної концептуальної метафори BLACK ECONOMY IS SOME OTHER ECONOMY, яка закладена у когнітивну основу досліджуваних евфемізмів (див. рис. 1). Ця метафора, своєю чергою, потребує метонімічного розширення для осягнення джерела метафори, оскільки простежується певний метонімічний зв'язок (за суміжністю) між евфемізмом та самим явищем, яке він позначає. Тобто можемо говорити про метафтонімію, яка утворюється у взаємодії метафори та метонімії і $є$ когнітивним механізмом дії, що лежить в основі досліджуваних евфемізмів.

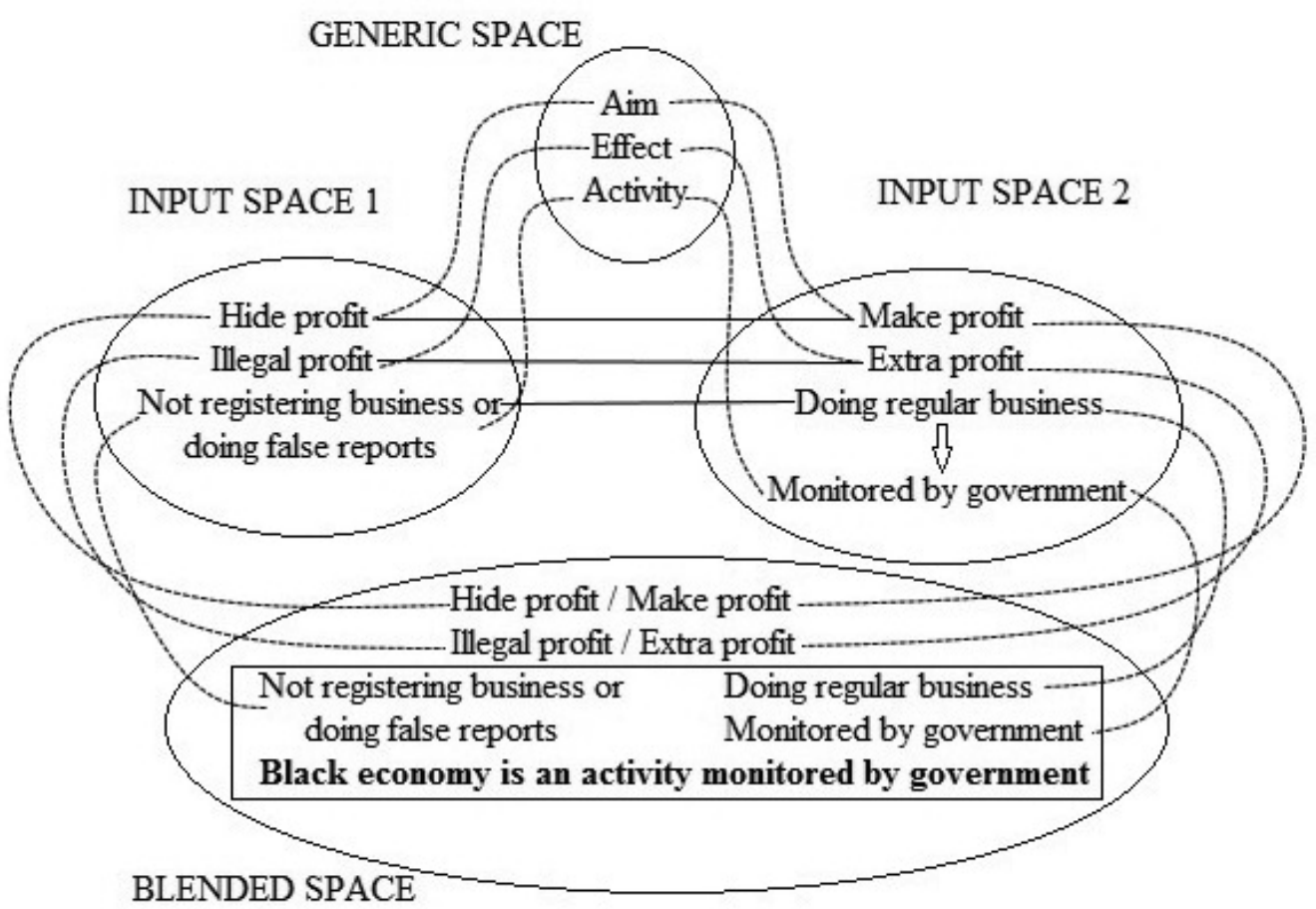

Рис. 1. Концептуальна мережа: BLACK ECONOMY IS SOME OTHER ECONOMY 
У вхідному просторі 1 розвивається сценарій тіньової економіки, а у вхідному просторі 2 - сценарій іншої економіки. До родового простору входять елементи, властиві двом вхідним просторам, а саме ціль, ефект, діяльність.

Спочатку на вихідний простір проектуються співставлені елементи, які в цьому просторі зливаються в одне ціле і стають одним спільним елементом для своїх відповідників з простору 1 та простору 2, а саме елементи мети приховати дохід/ приносити дохід та елементи ефекту нелегальний дохід/додатковий дохід. Отже, робиться наголос саме на доході, на тому що він $\epsilon$, але в тіні залишається його неоподаткованість. Вихідний простір також розвиває новий смисл, який є результатом співставлення невідповідних елементів діяльності незареєстрована діяльність або неправдива звітність/закономірна діяльність, які входять до вихідного простору окремими елементами i, своєю чергою, ще й протилежні стосовно один одного. Однак елемент діяльності простору 2 закономірна діяльність має ще й метонімічний зв'язок у межах одного простору (за суміжністю) із елементом контрольована владою, оскільки влада мусить регламентувати будь-яку правомірну діяльність. Отже, таке метонімічне розширення та співставлення непоєднуваних та ще й протилежних елементів діяльності веде нас до висновку, що тіньова економіка це діяльність, контрольована владою. Така евфемізація не викликає обурення у реципієнтів, адже якщо влада контролює тіньову економіку, то вона повинна бути оподаткованою. Тіньова економіка подається як правомірна діяльність, а реципієнти сприймають ії як звичайне економічне явище, що існує паралельно до державної економіки. Зазначимо, що ряд дій тіньової економіки (виробництво, послуги, торгівля, експорт, імпорт) збігається з низкою дій правомірної і відрізняється лише ухилянням від податків. При такій евфемізації наголошується тільки діяльність, що сприяє прирівнюванні тіньової економіки до правомірної. Така двозначність робить евфемізми “прихованими” в політичному дискурсі, чим вони передусім завдячують метафтонімії в їхній основі.

Ухиляння від податків $є$ негативним явищем, яке зазвичай засуджується за несправедливість, оскільки практично всі громадяни повинні бути платниками податків. Хабарництво - ще одне негативне явище, яке викликає обурення в реципієнтів, оскільки воно підриває такі суспільні засади, як рівноправність та справедлива конкуренція. До нашої вибірки увійшли евфемізми на позначення ухиляння від податків та хабарництва, які можна звести до метафори UNWITNESSED PAYMENT: under the counter (wages paid without deduction of tax), under the table (wages paid in cash without deduction of tax, bribery), on the side (untaxed income, bribery), income protection (arranging your affairs to avoid tax), backdoor (involving bribery), bagman (a passer of bribes), shade (to influence illegally). Нижче проаналізуємо деякі з вищевказаних евфемізмів у контексті. Перший приклад: < ..> oligarchs like Mr. Vekselberg are completely locked out of the American financial system, unable to rely on relatives or colleagues in the country to open a backdoor (The New York Times, 01/07/2019).

У цьому фрагменті евфемізм backdoor постає для реципієнтів як запасний невидимий та надійний вихід із скрутної ситуації, яким можна скористатись при наявності друзів чи родичів; адже саме для непомітності і надійності слугує запасний хід. 
Другий приклад: Individuals who work under the table are unlikely to report their jobs, especially if they are undocumented immigrants (The New York Times, 30/08/2010).

Евфемізм under the table дає розуміння того, що оплата здійснюється приховано, але не вказує на причину такого способу оплати. На перший план виходить спосіб, а причина - ухиляння від податків - залишається поза увагою. Тут можемо простежити спільну метонімічну модель СПОСІБ замість ДІЇ, де дія - неправомірна економічна діяльність та хабарництво.

Для осягнення джерела метафори, яка закладена в основу вищенаведених евфемізмів та виокремлення їхніх лінгвокогнітивних характеристик, потрібне метонімічне розширення, оскільки існує певний метонімічний зв'язок між евфемізмом та явищем, яке він позначає. Вищенаведені евфемізми зводимо до спільної концептуальної метафори BLACK ECONOMY IS UNWITNESSED INCOME. Це стає можливим саме завдяки метонімічному розширенню метафоричного джерела, яке проілюстровано далі (див. рис. 2).

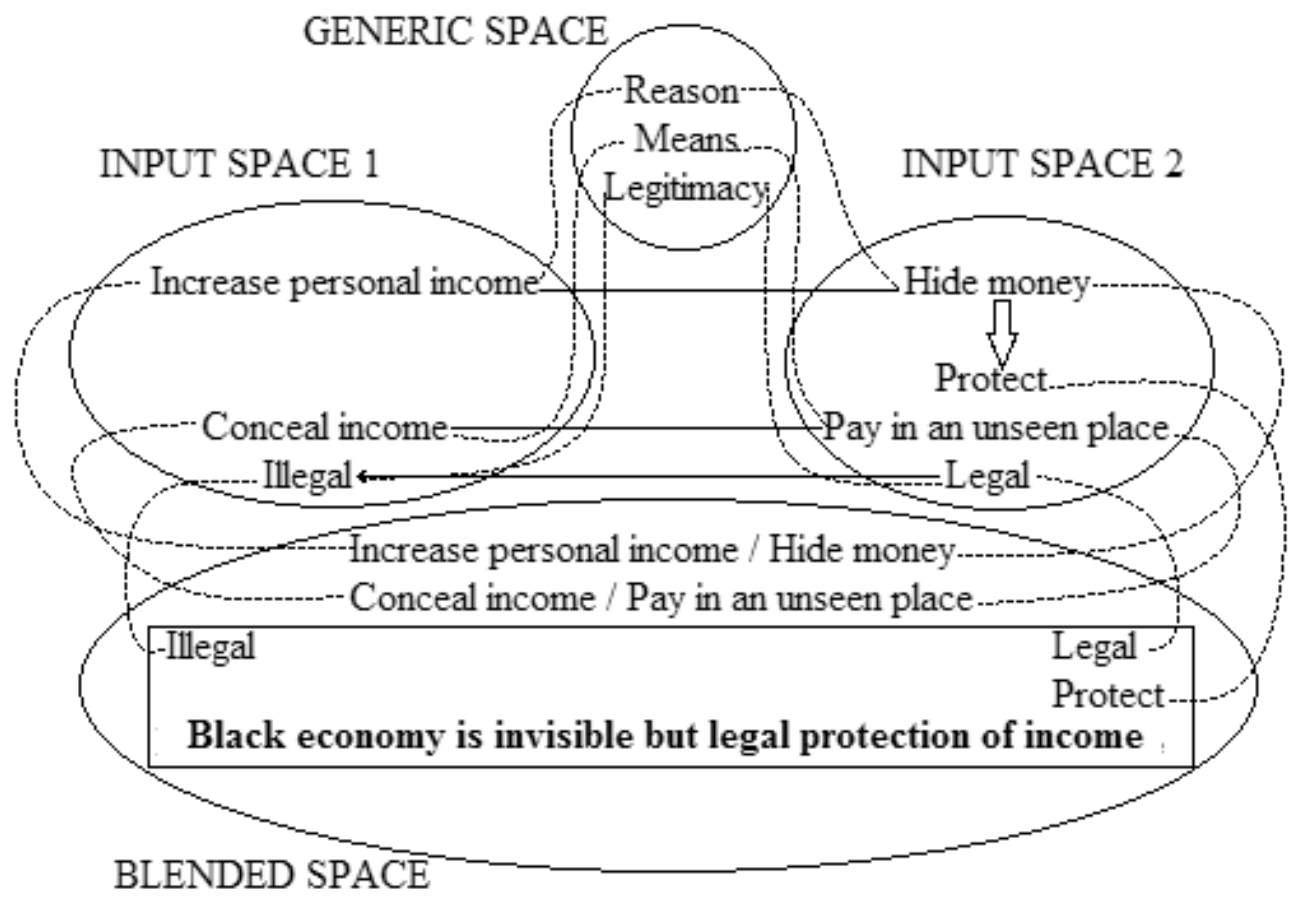

Рис. 2. Концептуальна мережа: BLACK ECONOMY IS UNWITNESSED INCOME

У вхідному просторі 1 розвивається сценарій тіньової економіки, а у вхідному просторі 2 - сценарій непомітного доходу. Родовий простір відображає структури, властиві двом вхідним просторам, тобто елементи причини, засобів та законності, між якими встановлюється зв'язок. 
На вихідний простір відбувається проекція співставлених елементів із двох вхідних просторів, які в цьому просторі зливаються в одне ціле. Це елементи причини збільшити особистий дохід/сховати гроші та засобу приховати дохід/платити у непомітному місиі. Вихідний простір також розвиває новий смисл, який є результатом співставлення невідповідних елементів законності тіньової політики (незаконний) та непомітної оплати (законний), які входять до вихідного простору окремими елементами, протилежними стосовно один одного. Отже, ухиляння від податків чи хабарництво не акцентується, а самі ці явища подаються як оплата, що була здійснена без свідків. Це, своєю чергою, не свідчить про злочин, оскільки сам факт приховування доходів може мати різні причини, приміром, як забобонні, так і цілком практичні. Сховати гроші у вхідному просторі 2, окрім метафоричного зв’язку (за схожістю) із елементом простору 1 збільшити особистий дохід (які зливаються і до вихідного простору входять одним елементом), має ще й метонімічний зв'язок (за суміжністю) захистити в межах вхідного простору 1.

Таке метонімічне розширення та співставлення непоєднуваних і до того ж протилежних елементів законності скеровує нас до основного висновку, який і $є$ тим новим смислом, що розвиває вихідний простір: тіньова економіка $є$ невидимим, але легальним захистом доходу. Таким чином, уникання податків сприймається реципієнтами як дія, необхідна задля безпеки доходу, а те, що це може призвести до браку коштів у державному бюджеті і негативно вплинути на кожного громадянина зокрема, залишається поза увагою. Хабарництво своєю чергою постає перед реципієнтами як певна оплата за якусь річ чи послугу без розголосу заради захисту здійснення цієї ж оплати. Отже, негативні явища тіньової економіки постають як такі, що не викликають асоціацій із незаконними діями, адже коли людина робить щось непомітно, її головна мотивація - вберегти щось важливе.

Висновки та перспективи подальших досліджень. Результати дослідження лінгвокогнітивних характеристик евфемізмів американського політичного англомовного дискурсу у світлі теорії концептуальної інтеграції дають змогу стверджувати, що основою евфемізмів може бути метафтонімія. Метонімічні зв'язки як складові метафтонімії скеровують реципієнта до побудови позитивного сценарію, активізуючи певні елементи 3 більш позитивної сфери знань порівняно з денотатом [6, с. 44]. Саме завдяки метонімічним зв'язкам нам вдалось відтворити сфери SOME OTHER ECONOMY та UNWITNESSED PAYMENT як джерела для метафор і проаналізувати евфемізми, утворені на їх основі. При такій евфемізації тіньової економіки наголошуються діяльність і дохід, що ставить їі в один ряд із правомірною державною економікою, причому нелегальність дій залишається поза увагою реципієнтів.

Ми також простежили конфлікт протилежних смислів в основі евфемізмів, що грунтуються на метафтонімії. Такий конфлікт присутній у метафорі BLACK ECONOMY IS SOME OTHER ECONOMY (not registering business or doing false reports/doing regular business) та у метафорі BLACK ECONOMY IS UNWITNESSED PAYMENT (illegal/ legal).

Отже, лінгвокогнітивний аналіз дає змогу стверджувати, що евфемізми тіньової економіки в американському англомовному політичному дискурсі, основані на метафтонімії, є прихованими у дискурсі. Такі евфемізми проникають у дискурс, 
“маскуючись” під одиниці первинної номінації. Вони не ідентифікуються реципієнтами як евфемізми, набувають широкого вжитку і витісняють прямі найменування. Вищенаведений аналіз, а також результати наших попередніх розвідок $[4 ; 5 ; 6]$ дають підстави говорити про тенденцію конфлікту протилежних смислів в евфемізації американського політичного дискурсу, оскільки евфемізми доволі часто поєднують в собі контрасти, навіть якщо вони не відтворені семантично та виражені імпліцитно. Така тенденція конфлікту протилежних смислів при евфемізації свідчить про зростання потенціалу евфемізмів та невидимого політичного маніпулювання у політичному дискурсі.

Перспективами подальших наукових розвідок вважаємо дослідження лінгвокогнітивних характеристик евфемізмів із застосуванням теорії концептуальної інтеграції інших лексико-семантичних розрядів.

\section{СПИСОК ВИКОРИСТАНОї ЛІТЕРАТУРИ}

1. Болдырев Н. Н., Алексикова Ю. В. Когнитивный аспект эвфемизации (на материале английского языка) // Вопросы когнитивной лингвистики. - Тамбов, 2010. - № 2. C. 5-11.

2. Великорода В. Б. Семантичні та функціонально-прагматичні характеристики евфемізмів в англійській мові : Автореф. дис. на здобуття наук. ст. канд. філол. наук. - Львів, 2008. -20 c.

3. Дойчик О. Я. Ідіостиль Джуліана Барнса у лінгвоконцептуальному вимірі: Автореф. дис. на здобуття наук. ст. канд. філологічних наук/Дойчик О.Я. - Харків, 2012. - 20с.

4. Небелюк Л. Р. Концептуально-метафорична евфемізація через протилежні сфери знань в американському англомовному політичному дискурсі / Л. Р. Небелюк // Актуальні проблеми романо-германської філології та прикладної лінгвістики. - Чернівці, 2017. - № 2 (15). - C. 81-85.

5. Небелюк Л. Р. Лінгвокогнітивні характеристики евфемізмів брехні англомовного американського політичного дискурсу у світлі теорії концептуальної інтеграції / Л. Р. Небелюк // Наукові записки ВДПУ. Серія: Філологія (мовознавство). - Вінниця, 2017. - Вип. 24. - С. 234-239.

6. Небелюк Л. Р. Лінгвокогнітивні характеристики евфемізмів американського англомовного політичного дискурсу, утворених на основі метафтонімії / Л. Р. Небелюк. // Science And Education a New Dimension. Phylology. - Budapest, 2019. - №195. C. $42-45$.

7. Шарманова О. С. Метафтонимия как концептуальное взаимодействие метафоры и метонимии / О. С. Шарманова // Вестник Иркутского государственного лингвистического университета. - 2011. - № 1. - С. 194-200.

8. Cambridge Dictionary [Electronic resource] - Access mode : https://dictionary.cambridge. org/dictionary/english/black-economy.

9. Collins Dictionary of Business, $3^{\text {rd }}$ ed. [Electronic resource] - Access mode : https:// financial-dictionary.thefreedictionary.com/merger+accounting

10. Fauconnier G., Turner M. Conceptual Integration Networks / Fauconnier G., Turner M. // Cognitive science. - 1998. - Vol. 22(2). - P. 1-72. [Electronic resource] - Access mode : http://www.cogsci.ucsd.edu/ faucon/ BEIJING/CIN.pdf

11. Goossens, L. Metaphtonymy: The interaction of metaphor and metonymy in expressions for linguistic action [Text] / L. Goossens // Metaphor and Metonymy in comparison and 
contrast / ed. by Rene Dirven, Ralf Porings. - Berlin; N.Y. : Mouton de Gruyer, 2002. P. $349-377$

12. Grady J. E., Oakley T., Coulson S. Blending and Metaphor / J. E. Grady, T. Oakley, S. Coulson // [Metaphor in cognitive linguistics, G. Steen \& R. Gibbs (eds.)]. - Philadelphia: John Benjamins, 1999. - P. 101-124.

13. Holder R. W. How Not to Say What You Mean: Dictionary of Euphemisms. - NY : Oxford University Press Inc., 2008. - 412 p.

14. Ruiz de Mendoza F., Galera Masegosa A. Going beyond metaphtonymy: Metaphoric and metonymic complexes in phrasal verb interpretation / F. Ruiz de Mendoza, A. Galera Masegosa // Language Value, 2011. - Vol. 3, - P. 1-29.

\section{СПИСОК ВИКОРИСТАНИХ ДЖЕРЕЛ}

15. The New York Times [Electronic resource]. - Access mode : https://www.nytimes.com.

16. The Washington Post [Electronic resource]. - Access mode : https://www.washingtonpost. com.

\section{REFERENCES}

1. Boldyriev N. N., Alieksikova Y. V. Kohnitivnyi aspect evfemizatsyi (na matierialie anhliiskoho yazyka) [Conceptual aspect of euphemisation (on the English language material)] // Vaprosy kohnitivnoi linhvistiki. - Tambov, 2010. - № 2. - C. 5-11.

2. Velykoroda V. B. Semantychni ta funktsionalno-prahmatychni kharakterystyky evfemismiv $\mathrm{v}$ anhliiskii movi [Semantic, functional and pragmatic characteristics of euphemisms in the English language]: Avtoref. dys. na zdobuttia nauk. st. filol. nauk. - Lviv, 2008. - $20 \mathrm{~s}$.

3. Doichyk O. Y. Idiostyl Dzuliana Barnsa u linhvokontseptualnomu vymiri [Idiostyle of Julian Burnes in linguoconceptual dimension]: Avtoref. dys. na zdobuttia nauk. st. kand. filolohichnykh nauk. - Kharkiv, 2012. - $20 \mathrm{~s}$.

4. Nebeliuk L. R. Kontseptualno-metaforychna evfemizatsiia cherez protylezhni sfery znan v amerykanskomu anhlomovnomu politychnomu dyskursi [Conceptual metaphorical euphemisation through opposite spheres of knowledge in the English language American political discourse] / L. R. Nebeliuk // Aktualni problemy romano-hermanskoi filolohii ta prykladnoi linhvistyky. - Chernivtsi, 2017. - № 2 (15). - S. 81-85.

5. Nebeliuk L. R. Linhvokohnityvni kharakterystyky evfemismiv brekhni anhlomovnoho amerykanskoho dyskursu u svitli teorii kontseptualnoii intehratsii [Linguocognitive characteristics of euphemisms denoting lies in American political discourse in the light of conceptual integration theory] / L. R. Nebeliuk // Naukovi zapysky VDPU. Seriia: Filolohiia (movoznavstvo). - Vinnytsia, 2017. - Vyp. 24. - S. 234-239.

6. Nebeliuk L. R. Linhvokohnityvni kharakterystyky evfemismiv amerykanskoho anhlomovnoho politychnoho dyskursu, utvorenykh na osnovi metaftonimii [Linguocognitive characteristics of euphemisms based on metaphtonymy in American political discourse] // Science and Education: A New Dimension. Phylology. - Budapest, 2019. - № 195. C. $42-45$.

7. Sharmanova O. S. Metaftonimiia kak kontseptualnoie vzaimodeistviie mietafory I mietonimii [Metaphtonymy as the conceptual interaction of metaphor and metonymy / O. S. Sharmanova] / O. S. Sharmanova // Vestnik Irkutskoho hosydarstviennoho linhvistichieskoho univiersitieta. - 2011. - № 1. - S. 194-200. 
8. Cambridge Dictionary [Elektronnyi resurs] - Rezhym dostupu do resursu: https://dictionary. cambridge.org/dictionary/english/black-economy.

9. Collins Dictionary of Business, $3^{\text {rd }}$ ed. [Elektronnyi resurs] - Rezhym dostupu do resursu: https://financial-dictionary.thefreedictionary.com/merger+accounting.

10. Fauconnier G., Turner M. Conceptual Integration Networks / Fauconnier G., Turner M. // Cognitive science. - 1998. - Vol. 22(2). - P. 1-72. [Elektronnyi resurs] - Rezhym dostupu: http://www.cogsci.ucsd.edu/ faucon/ BEIJING/CIN.pdf

11. Goossens, L. Metaphtonymy: The interaction of metaphor and metonymy in expressions for linguistic action. [Text] / L. Goossens // Metaphor and Metonymy in comparison and contrast / ed. by Rene Dirven, Ralf Porings. - Berlin; N.Y. : Mouton de Gruyer, 2002. P. 349-377.

12. Grady J. E., Oakley T., Coulson S. Blending and Metaphor / J. E. Grady, T. Oakley, S. Coulson // [Metaphor in cognitive linguistics, G. Steen \& R. Gibbs (eds.)]. - Philadelphia: John Benjamins, 1999. - P. 101-124.

13. Ruiz de Mendoza F., Galera Masegosa A. Going beyond metaphtonymy: Metaphoric and metonymic complexes in phrasal verb interpretation / F. Ruiz de Mendoza, A. Galera Masegosa // Language Value, 2011. - Vol. 3. - P. 1-29.

\title{
SOURCES
}

14. The New York Times [Electronic resource]: https://www.nytimes.com.

15. The Washington Post [Electronic resource]: https://www.washingtonpost.com.

\section{METAPHTONYMY \\ AS A BASIS OF "BLACK ECONOMY" EUPHEMISMS IN AMERICAN POLITICAL DISCOURSE}

\author{
Lesia Nebeliuk
}

\author{
Vasyl Stefanyk Precarpathian National University, \\ 12, Shevchenko Str., Ivano-Frankivsk, Ukraine, 76018 \\ lesia.nebeliuk@gmail.com
}

The article deals with the analysis of euphemisms denoting "black economy" in American political discourse, which are based on metaphtonymy. Although the phenomenon of euphemisation has been widely studied, the linguocognitive characteristics of euphemisms in American political discourse and their influence on the recipients have not yet been established. The aim of this article is to analyze euphemisms based on metaphtonymy, which denote "black economy" in American political discourse. The author reveals lexicalsemantic components from the addressee's spheres of knowledge that contribute to ameliorated, positive perception of the nominations through metaphtonymy, and applies conceptual integration theory to the analysis of the metaphtonymies on which the euphemisms under study are based. The conceptual integration 
theory typically makes use of a four-space model. These spaces include two "input" spaces (which, in a metaphorical case, are associated with the source and target of the conceptual metaphor theory), plus a "generic" space, representing the conceptual structure which is shared by both inputs, and the "blend" space, where material from the inputs combines and interacts. The study of linguocognitive characteristics of euphemisms with the application of the conceptual integration theory allows tracing and analyzing the emergence of a new ameliorated sense created by euphemisms. It becomes possible due to the process which takes place in the blend when two incongruous elements from input spaces interact. The euphemisms denoting "black economy" were selected from the political texts of "The Washington Post" and "The New York Times" published in 2003-2019. It was established that such euphemisms as "merger accounting", "parallel importer", "informal market", "expenses" are based on the conceptual metaphors with metonymic extension "BLACK ECOMOMY IS SOME OTHER ECONOMY," and euphemisms "under the counter", "under the table", "on the side", "income protection", "backdoor", "bagman", "hush money", "shade" are based on the conceptual metaphor "BLACK ECONOMY IS UNWITNESSED PAYMENT". As a result of such conceptualizations, black economy appears as some regular economic activity which is monitored by government, or an activity which is realized for the protection of income. The analysis shows that euphemisms based on the conceptual metaphors with metonymic extension listed above are able to influence the recipient's associative perception. The result of such influence is a positive or neutral recipient's reaction to such a negative phenomenon as black economy. Also, a tendency to integrate hidden opposite senses has been observed. Therefore, a logical demarcation line between notions and euphemisms disappears.

Key words: euphemism, conceptual metaphor, metonymy, metaphtonymy, conceptual integration, political discourse. 